\title{
Use of LIDAR in landslide investigations: a review
}

\author{
Michel Jaboyedoff • Thierry Oppikofer • Antonio Abellán • \\ Marc-Henri Derron • Alex Loye • Richard Metzger • Andrea Pedrazzini
}

Received: 12 February 2010/Accepted: 24 September 2010/Published online: 19 October 2010

(C) The Author(s) 2010. This article is published with open access at Springerlink.com

\begin{abstract}
This paper presents a short history of the appraisal of laser scanner technologies in geosciences used for imaging relief by high-resolution digital elevation models (HRDEMs) or 3D models. A general overview of light detection and ranging (LIDAR) techniques applied to landslides is given, followed by a review of different applications of LIDAR for landslide, rockfall and debris-flow. These applications are classified as: (1) Detection and characterization of mass movements; (2) Hazard assessment and susceptibility mapping; (3) Modelling; (4) Monitoring. This review emphasizes how LIDARderived HRDEMs can be used to investigate any type of landslides. It is clear that such HRDEMs are not yet a common tool for landslides investigations, but this technique has opened new domains of applications that still have to be developed.
\end{abstract}

Keywords Landslide · LIDAR · Laser scanner · High-resolution DEM · Topography analysis · Structural analysis

\section{Introduction}

Remote sensing techniques for landslides investigations are undergoing rapid developments. The possibility of acquiring 3D information of the terrain with high accuracy and high spatial resolution is opening up new ways of investigating the landslide phenomena. Recent advances in sensor electronics and data treatment make these techniques affordable. The two major remote sensing techniques that are exponentially developing in landslides investigation are interferometric synthetic aperture radar (InSAR) (Fruneau et al. 1996; Colesanti et al. 2003; Squarzoni et al. 2003), and light detection and ranging (LIDAR) (Carter et al. 2001; Slob et al. 2002; Haugerud et al. 2003; Slob and Hack 2004). InSAR techniques are usually ground-based (Stow 1996; Tarchi et al. 2003) or satellite-based

M. Jaboyedoff $(\bowtie) \cdot$ A. Abellán · M.-H. Derron · A. Loye · R. Metzger · A. Pedrazzini Institute of Geomatics and Risk Analysis, University of Lausanne, 1015 Lausanne, Switzerland e-mail: michel.jaboyedoff@unil.ch

T. Oppikofer

Geological Survey of Norway, 7491 Trondheim, Norway 
(Carnec et al. 1996; Singhroy 2009), and only rarely airborne. InSAR techniques are mainly dedicated to the detection and the quantification of small displacements over large areas. LIDAR (or laser scanning) provide high-resolution point clouds of the topography and has several applications that range from mapping (Ardizzone et al. 2007; Jaboyedoff et al. 2008a) to monitoring deformation (Gordon et al. 2001), landslides or rockfall displacements (Teza et al. 2007; Oppikofer et al. 2008; Abellan et al. 2010) to landslide in soils (Jaboyedoff et al. 2009a). The joint use of terrestrial laser scanning (TLS) and SAR techniques may help to understand landslide phenomena, as is discussed in Teza et al. (2008).

LIDAR is mainly used for landslide investigation to create accurate and precise highresolution digital elevation models (HRDEM) in raster grids or triangulated irregular networks (TINs), which are $2.5 \mathrm{D}$ representations of the topography, or in true 3D point clouds with a high density of information. This density mainly depends on the position of the sensor: metric to decimetric resolution for airborne laser scanning (ALS) and centimetric to millimetric resolution for terrestrial laser scanning (TLS) (Shan and Toth 2008). Helicopter-based ALS can give a higher resolution than aircraft-based ALS and especially allows orientating the scanner in all directions (Vallet and Skaloud 2004).

The number of publications discussing the use of LIDAR in landslide studies has grown considerably during the last decade (Derron and Jaboyedoff 2010). Main applications range from mapping to monitoring and modelling slope mass movements. Two books were recently published: "Topographic laser ranging and scanning", by Shan and Toth (2008) and "Laser Scanning for the Environmental Sciences", by Heritage and Large (2009). The former provides a comprehensive compilation of the principles and fundamentals of LIDAR technologies, reflecting the state-of-the-art of all the physical aspects of the sensor (components, calibration, waveform analysis, quality control of LIDAR data, filtering and feature extraction techniques, etc.). Although some of the chapters may be slightly focused on the geomatics field (and hence, out of the scope for the readers of this review), the first three chapters by Petrie and Toth (2008) are an excellent basis for the understanding of instrumental issues: Chapter 1 describes basic (and not so basic) principles of laser profiling and scanning; Chapters 2 and 3 perform a detailed description of the main commercial and research systems currently available on the market for aerial and terrestrial LIDAR, respectively. As regards the book edited by Heritage and Large (2009), it provides numerous LIDAR applications to environmental sciences, being of great value for researches in the field of geomorphology, geostatistics, remote sensing and Geographic Information Systems (GIS). The contributions can be mainly divided into mapping (flooding areas, vegetation), geometrical aspects (study of geological outcrops and river gravel bars) and monitoring (rocky and sandy coastal erosion, river dynamics, etc.). Unfortunately, up to now there has been little effort to review the advances of LIDAR applications on landslides. This paper tries to fill this gap.

\section{Laser scanning and/or LIDAR techniques}

\subsection{Short overview about LIDAR techniques and rangefinder}

The acronym LASER (or laser) stands for Light Amplification by Stimulated Emission of Radiation. A laser is a device that produces and emits a beam (or a pulse series) of highly collimated, directional, coherent and in-phase electromagnetic radiation. As shown below, laser systems can be used for the acquisition of large amounts of $3 \mathrm{D}$ information of the 


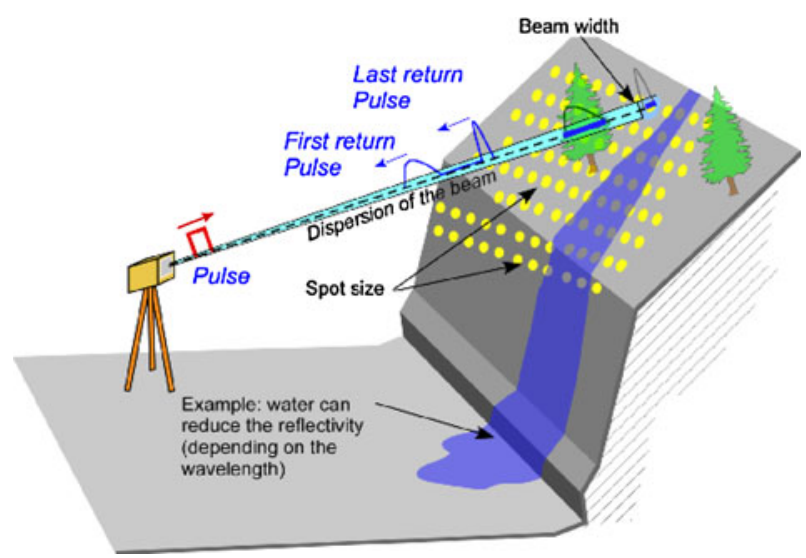

Fig. 1 Principles of laser scanner data acquisition, showing the example of TLS

terrain at an extremely fast recording rate (Fig. 1). Although LIDAR is a term commonly used in literature, laser scanner or laser range finder are preferred, which makes the link with past methods (laser ranging and laser profiling).

Laser scanning was developed in two ways, depending on the position of the sensor: airborne-based for ALS and ground-based for TLS. Basic principles and processing of the former are well-known issues since the end of the 1990s. A complete review of ALS systems can be found in Wehr and Lohr (1999) and in Baltsavias (1999). An updated and clear reference is the already commented book of Shan and Toth (2008). Literature on TLS has rapidly grown during the last 5 years (2005-2010). Petrie and Toth (2008) are a good reference for understanding basic principles of TLS. Detailed guidelines that should rule the use of the TLS in all the projects managed by the California Department of Transportation was written by Hiremagalur et al. (2007). Although an environmental scientist may have found this lecture out of the scope of his field of research, it provides useful information on standards and specifications for the quality control of different TLS. Finally, a brief review of LIDAR (and other conventional remote sensing techniques) applied to landslide monitoring is found in Prokop and Panholzer (2009) and in SafeLand Deliverable 4.1 (2010). A combination of both techniques, ALS and TLS, is frequently used to solve some acquisition problems for example the shadow areas when a scanned surface is parallel to the line of sight (LOS) of one of the sensor.

\subsubsection{Measurement principle}

A laser scanner consists of a transmitter/receiver of laser beam and a scanning device. Two different methods for range determination are possible (Wehr and Lohr 1999): phase and pulse method. The former allows more accurate range determination but suffers from a limited range (Petrie and Toth 2008). Alternatively, the latter allows a greater range, and is therefore implemented in most ALS and TLS used for Earth surface observations, including landslide studies (Wehr and Lohr 1999; Baltsavias 1999).

Both airborne- and ground-based sensors send out laser pulses that get back-scattered by various objects (ground surface, vegetation, man-made constructions etc.) and record the returning signal. Pulsed laser scanners use the measurement of the time of flight $(\Delta t)$ of the laser pulse to compute the distance $(2 \times \mathrm{d}=\mathrm{c} \times \Delta \mathrm{t})$ and mirrors or mechanics to 
orientate the laser beam in a well-defined direction. Knowing this line of sight (LOS) direction and the attitude of the device (pitch, roll and yaw) allows determining the position $\Delta \mathrm{x}, \Delta \mathrm{y}, \Delta \mathrm{z}$ of a reflective surface relatively to the device. The range is measured without any artificial reflectors over an area equal to the laser's spot dimension (beam width projected on the topography), which increases with distance due to the laser beam divergence (Petrie and Toth 2008) (Fig. 1).

The absolute position of an ALS sensor is defined by a Global Positioning System (GPS), and its attitude is recorded by an inertial system. Finally, the point cloud coordinates are estimated $(\mathrm{x}+\Delta \mathrm{x}, \mathrm{y}+\Delta \mathrm{y}, \mathrm{z}+\Delta \mathrm{y})$ with an accuracy of around $15 \mathrm{~cm}(1 \sigma)$ by using ground control points (Habib 2008). In practice, the position and orientation (attitude) of the TLS sensor are not defined precisely in the field, unless the TLS device is also coupled with an inertial system and a GPS. This makes necessary a further georeferencing of the TLS point cloud. This process is carried out by aligning the TLS point cloud, either using a set of ground control points or using another already georeferenced point cloud.

\subsubsection{Analysis of back-scattered laser pulses}

Most ALS and a few of the TLS systems use the full waveform of the laser signal. The full waveform of the back-scattered pulse includes some information on the properties of the reflexive objects within the beam area. This allows for instance removing part of the vegetation effect (Duong 2006; Harding 2008; Heritage and Large 2009). Alternatively, range measurement using TLS can be undertaken without discriminating the full waveform, but recording several back-scattered pulses from one emitted pulse. This procedure makes it possible to distinguish and to filter intermediate-range objects (vegetation, wires, birds and other undesired points). For landslides applications, the last returned pulse is usually the most relevant. Nevertheless, if the vegetation is too dense the laser beam will not reach the ground, and direct visibility (LOS) between the TLS and the scanned surface is of course necessary. However, these limitations are common with other remote sensing techniques (surveying, radar and/or optical).

It must be said that one of the main issue in laser scanning is the removal of the vegetation (Harding 2008) either by automatic methods or manually. If vegetation is dense sometimes the DEM created from ALS data is not better than a standard resolution DEM (approx. $25 \mathrm{~m}$ grid size) obtained from topographic maps.

\subsubsection{Accuracy, resolution and point density}

The typical accuracy of the laser instrument is $\pm 1.5 \mathrm{~cm}$, within maximum distances of about 800-1,000 m (Manetti and Steinmann 2007). Nevertheless, the instrumental accuracy is usually lower in practical applications due to unfavourable conditions such as: poorly reflecting or very rough surfaces, parallel incident angles, bad weather conditions (rain or hot wind or fog), very bright ambient conditions, excessive range, etc.

Laser scanner's resolution is a parameter that determines the level of detail that can be observed in a point cloud. It is divided into range and angular (or spatial) resolution (Kamerman 1993; Lichti and Jamtsho 2006): (a) Range resolution is the ability of a rangefinder to resolve two objects on the same LOS; (b) Angular resolution is the ability to resolve two objects on adjacent LOS. This parameter is governed by two variables: sampling interval (also called point spacing, which is user defined) and laser beamwidth (which depends on the distance and the instrument). The estimation of the TLS resolution is usually misunderstood and commonly interpreted as equal to the point spacing, obviating 
the influence of the laser beamwidth. Nevertheless, when sampling interval is lower than the laser beamwidth, fine details are in fact blurred. A detailed explanation of this effect can be found in Lichti and Jamtsho (2006). They proposed the use of the effective instantaneous field of view (EIFOV) as a measurement of the resolution of the TLS. The lower sampling interval proposed by these authors is $86 \%$ of the laser beamwidth.

For ALS, the point density usually ranges from 0.5 to $100 \mathrm{pts} / \mathrm{m}^{2}$, while for TLS it ranges usually from 50 to $10,000 \mathrm{pts} / \mathrm{m}^{2}$. In addition to the position, the intensity of the reflected signal is acquired. This parameter mainly depends on the beam wavelength, the type of material (colours and roughness of the reflective surface), soil moisture and angle of incidence (Ingensand 2006; Lichti 2007; Pesci et al. 2008; Voegtle et al. 2008).

The wavelength ranges between 500 and 1,700 nm (Wehr and Lohr 1999; Jaboyedoff et al. 2009a). For TLS, the acquisition range increases usually with longer wavelengths, from a few metres to 2,000 $\mathrm{m}$ if reflectivity of the surface is high (Jaboyedoff et al. 2009a).

\subsubsection{Point cloud alignment}

Alignment of the point cloud usually consists of a two-step process: a preliminary registration by a visual identification of homologous points and an optimization of the alignment using an Iterative Closest Points (ICP) procedure (Besl and McKay 1992; Chen and Medioni 1992). Using this algorithm, the differences between points are iteratively reduced by a minimization of a mean square cost function. Alternatively, the alignment over discrete parts of the slope can be carried out using the Roto-Translation technique described by different authors (Teza et al. 2007; Monserrat and Crosetto 2008; Oppikofer et al. 2009).

\subsection{Short historical overview}

Early attempts to acquire Earth surface data sets by ALS were performed along profiles using only an inertial system and other positioning technique for topographic mapping (Miller 1965; Krabill et al. 1984) with devices developed for water depth measurement (Hoge et al. 1980) or for altimetry purposes (Shepherd 1965). One of the first applications in geosciences of ALS (i.e., using inertial system coupled with GPS) has been to evaluate the topographical changes of the Greenland ice sheet (Krabill et al. 1995, 1999).

TLS appeared later than ALS at the end of the 1990s (Large and Heritage 2009). This instrument is an evolution of the electronic distance meter (EDM) and of total station, which benefits of the earlier ALS developments (many companies manufacturing ALS are now also selling TLS). EDM was developed during the late 1950s and early 1960s (Dallaire 1974). These instruments allow for a very accurate distance measurement. Nevertheless, these one-dimensional measurements were not suitable for the measurement of the 3D coordinates of single points $(\mathrm{x}, \mathrm{y}, \mathrm{z})$. Furthermore, reflectors are usually required (Bromhead et al. 1988). By contrast, TLS measurements include real 3D information (x, y, $\mathrm{z}$ coordinates) plus intensity (I), and in some cases full waveform. In addition, TLS devices are reflectorless (Petrie and Toth 2008) allowing for a broad coverage of the surveyed area. The early tests for environmental application were made in the late 1990s and in the early twenty-first century (Lichti et al. 2000).

A systematic bibliographic survey was carried out by Derron and Jaboyedoff (2010) looking within the databases ISI Web of Knowledge and GEOREF. In this paper, the growth of the yearly production of publications and citations related to LIDAR and geosciences or landslide is analysed through logistic functions. The main outcome of this 
analysis is that the community of geoscientists working with laser scanning techniques is presently building an innovative and useful knowledge and that this fast development has the potential to continue for the next 5-10 years.

\section{Classification of the main applications}

TLS and ALS can be used for different types of investigation, which can be subdivided in 4 types (Table 1): (1) Landslide detection and characterization; (2) Hazard assessment and susceptibility mapping; (3) Modelling; (4) Monitoring. This classification may have overlaps, but allows us to classify the main objectives of the research. Our classification is based not only on the type of mass movements described by Cruden and Varnes (1996) but also on the processes linked to these phenomena. The selected approach to study the mass movement is strongly dependant on the scanned object: (1) we refer as "rockfalls" to all the slope processes formed in rock slopes, from the detachment of the instability to the propagation; (2) we refer as "landslides" to all the material that suffer large scale and slow rate of deformation, in either soft, fine materials (soils) and/or weathered and weak rocky material, including deep-seated gravitational slope deformation (DSGSD) (Agliardi et al. 2009); finally, (3) we refer as "debris-flows" to slope movements formed by debris type of material, moving down the slope as a flow. This classification makes sense in terms of LIDAR analysis, because the analyses of the geomorphic features are not necessarily scale dependant. As an example, it can be impossible to distinguish a DSGSD from a classical landslide only by inspecting a hillshade relief without knowing the scale.

Table 1 Classification of the different applications of LIDAR technologies in landslide studies

\begin{tabular}{|c|c|c|c|}
\hline & Landslide & Rockfall & Debris-flow \\
\hline $\begin{array}{l}\text { (1) Landslide detection } \\
\text { and characterization } \\
\text { (In Sect. 4) }\end{array}$ & $\begin{array}{l}\text { - Mapping of geomorphic } \\
\text { features }\end{array}$ & $\begin{array}{l}\text { - Rock face imaging } \\
\text { and characterization } \\
\text { - Calculate } \\
\text { discontinuity } \\
\text { orientation }\end{array}$ & $\begin{array}{l}\text { - Detection of } \\
\text { mobilizable } \\
\text { volumes } \\
\text { - Hydromorphic } \\
\text { characterization }\end{array}$ \\
\hline $\begin{array}{l}\text { (2) Hazard assessment } \\
\text { and susceptibility } \\
\text { mapping (In Sect. 5) }\end{array}$ & $\begin{array}{l}\text { - Mainly as support for } \\
\text { mapping }\end{array}$ & $\begin{array}{l}\text { - Some attempts for } \\
\text { susceptibility and } \\
\text { hazard mapping (not } \\
\text { yet achieved) }\end{array}$ & $\begin{array}{l}\text { - Input for mapping } \\
\text { hazard based on } \\
\text { geomorphologic } \\
\text { approach }\end{array}$ \\
\hline $\begin{array}{l}\text { (3) Modelling } \\
\text { (In Sect. 5) }\end{array}$ & $\begin{array}{l}\text { - Classical modelling tools are } \\
\text { not able yet to handle huge } \\
\text { 3D information density } \\
\text { - HRDEM allow more accurate } \\
\text { landslide modelling by } \\
\text { improving their geometrical } \\
\text { characterization }\end{array}$ & $\begin{array}{l}\text { - High-resolution DEM } \\
\text { for trajectory } \\
\text { modelling }\end{array}$ & $\begin{array}{l}\text { - Input for spreading } \\
\text { modelling }\end{array}$ \\
\hline $\begin{array}{l}\text { (4) Monitoring } \\
\text { (In Sect. 6) }\end{array}$ & $\begin{array}{l}\text { - Monitoring of surface } \\
\text { displacements } \\
\text { - Volume budget }\end{array}$ & $\begin{array}{l}\text { - Monitoring of surface } \\
\text { displacement } \\
\text { - Detection of pre- } \\
\text { failure displacements } \\
\text { (under development) } \\
\text { - Quantification of } \\
\text { rockfall activity } \\
\text { (volumes) }\end{array}$ & $\begin{array}{l}\text { - Sediment budget } \\
\text { - Monitoring of } \\
\text { morphologic } \\
\text { changes in channel }\end{array}$ \\
\hline
\end{tabular}




\section{Detection and characterization of mass movements}

\subsection{Landslide}

\subsubsection{ALS}

ALS permits an improvement in the landslide inventory mapping and more generally of geological mapping (Borlat et al. 2007), by increasing the resolution of the landslide contours, permitting to identify scarps and displaced material. Nevertheless, the same conceptual methods to detect landslides are still usually employed (Soeters and Van Westen 1996; Keaton and DeGraff 1996). The morphological features of the landslides (e.g. scarps, mobilized material, foot) are easy to delineate based on hillshades of the produced HRDEM (Carter et al. 2001; Haugerud et al. 2003; Ardizzone et al. 2007; Jaboyedoff et al. 2008a; Corsini et al. 2009). This approach does not replace field investigations, but it changes the fieldwork methods, which become part of the validation processes of a landslide inventory produced by HRDEM analysis (Fig. 2).

The detection can be performed either manually (e.g. expert criteria such as eye inspection) or automatically (e.g. feature detection such as the curvature or roughness of the topography). McKean and Roering (2004) showed that spreading of topographic orientations within an earth-flow is higher than that in undisturbed area. An extension of this method using Fourier analysis of the relief demonstrates that this method can classify more
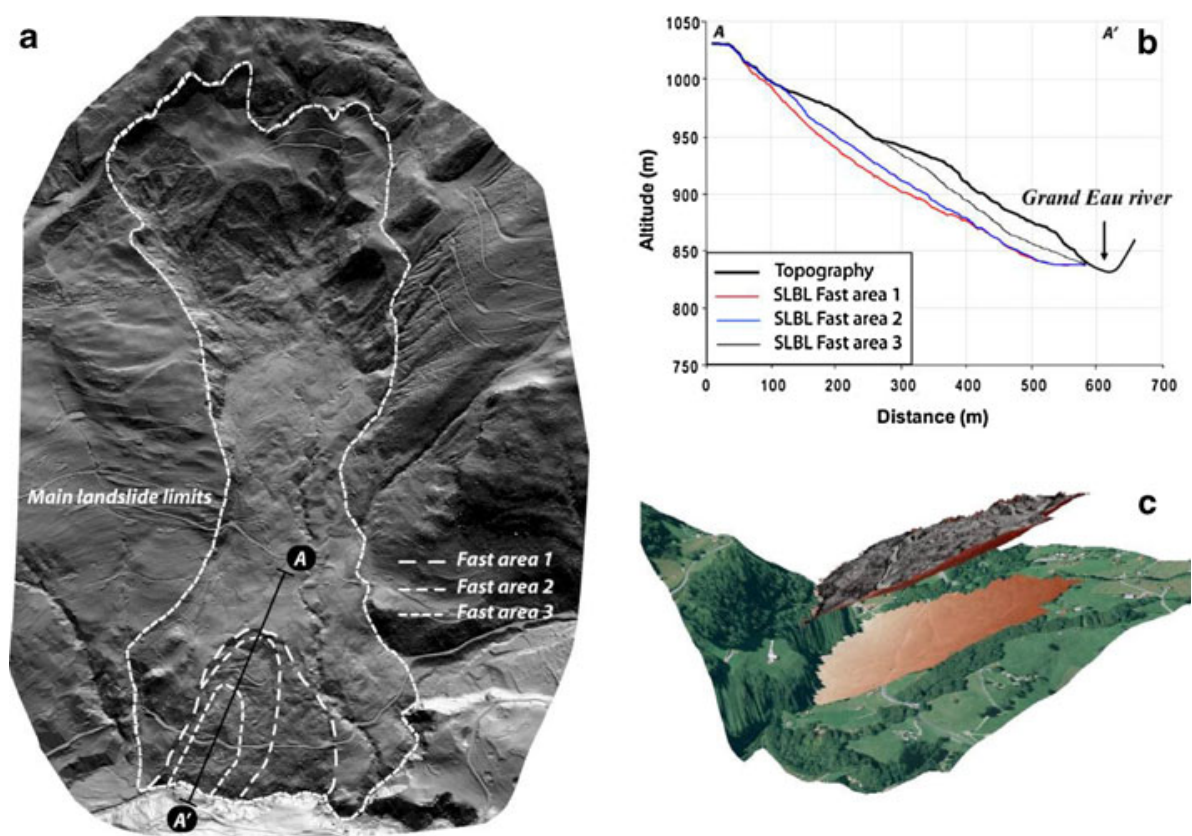

Fig. 2 La Frasse landslide (Switzerland): a 3D view of the shaded relief of the main landslide extent. Three sectors moving faster than the surrounding areas were identified at the toe of the landslide. b Cross-section through the fast-moving area showing the modelled failure surfaces obtained using the SLBL method (Jaboyedoff et al. 2004b). c 3D view of the volume of the faster area 3 (Data from swisstopo) 


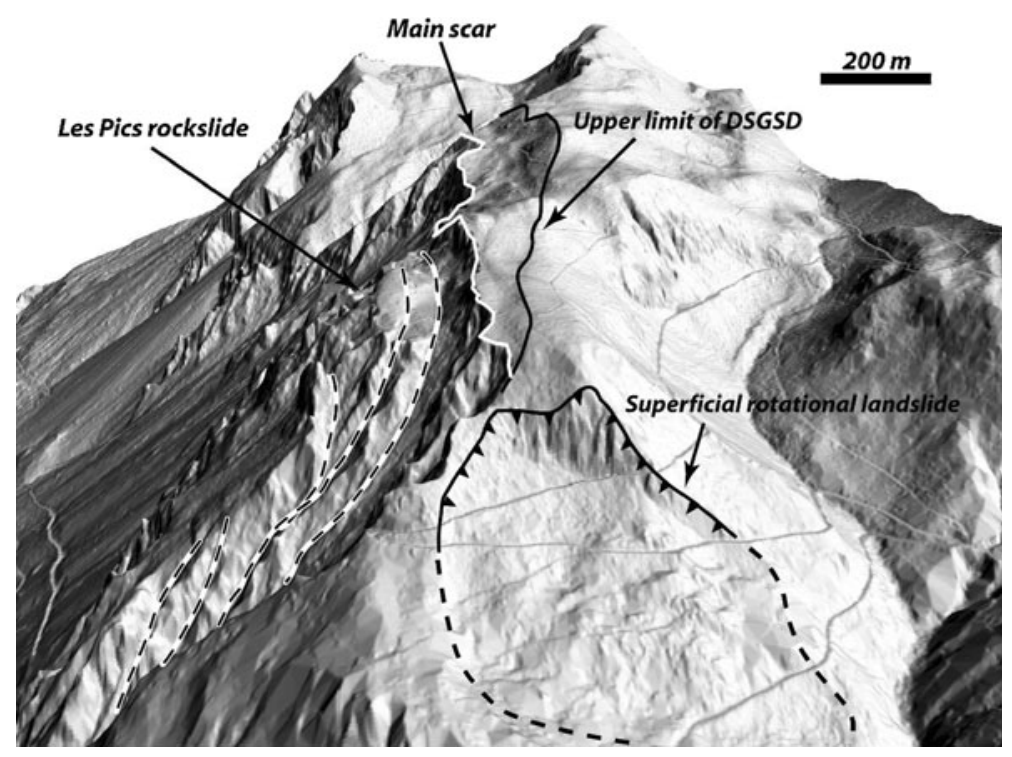

Fig. 3 Hillshade view of the upper part of Les Pics instability (Muraz, Switzerland). Gravitational features as scarps, trenches and depressions forming the "Les Pics DSGSD" could be clearly identified. The real instability extend could be better defined using LIDAR-derived DEM than in aerial photographs or from topographic maps (Data from swisstopo)

than $80 \%$ of total area that has already suffered a landslide (or not) in western US (Booth et al. 2009). Geomorphic criterion based on geostatistics (Glenn et al. 2006) succeeds in differencing landslide activities. Nevertheless, such methods are not easy to apply due to following reasons: (a) expert criteria are needed (interpretation of the results) and (b) the presence of vegetation may degrade the DEM quality (Kasai et al. 2009). In addition, the detailed morphology provided by HRDEM coupled with geologic information can allow forecasting of the sensitive zones even if the triggering is human induced (Schulz 2007). The interpretation of DSGSD is also improved by using HRDEM (Agliardi et al. 2009; Oppikofer 2009; Corsini et al. 2009) especially because it permits a precise delineation of the limits (Fig. 3).

\subsubsection{TLS}

Only few applications exist on landslide characterization (Rowlands et al. 2003), but in several cases TLS is a very useful tool to interpret the landslide mechanism, delineate limits and estimate volumes (Corsini et al. 2009; Dunning et al. 2009). Jaboyedoff et al. (2009a) shows a case study of circular landslides in silty sediments in river banks.

\subsection{Rockfall}

TLS and ALS techniques are responsible for a great improvement in rock slope characterization, mainly because the rock instabilities are principally controlled by structures that are at least locally planar. The TLS applications characterizing rock mass are numerous 
(Slob and Hack 2004; Jaboyedoff et al. 2007; Oppikofer et al. 2009; Sturzenegger and Stead 2009; Armesto et al. 2009; Lato et al. 2009), but still quite rare for ALS-DEM.

\subsubsection{ALS}

Structural analysis at regional scale are proposed using ALS-derived HRDEM using the principle of COLTOP (Jaboyedoff et al. 2004a, 2007, 2009b), which allows to attribute a unique colour for each topographic orientation. This permits also to create stereonets on the basis of plane orientations measured directly on the point cloud (Fig. 4). The main sets of structural features have been identified in several rockslides in Norway (Derron et al. 2005). This approach also allowed a fast structural characterization of the hardly accessible Mount Steele rockslide in Yukon, Canada (Brideau et al. 2009) and the reinterpretation of former rockslide such as Frank slide (Sturzenegger et al. 2007a; Froese et al. 2009). At regional scale, the fjord valley of Tafjord in Norway has been investigated in order to characterize the present and former rock slope instabilities, such as their volume and mechanisms (Oppikofer 2009).
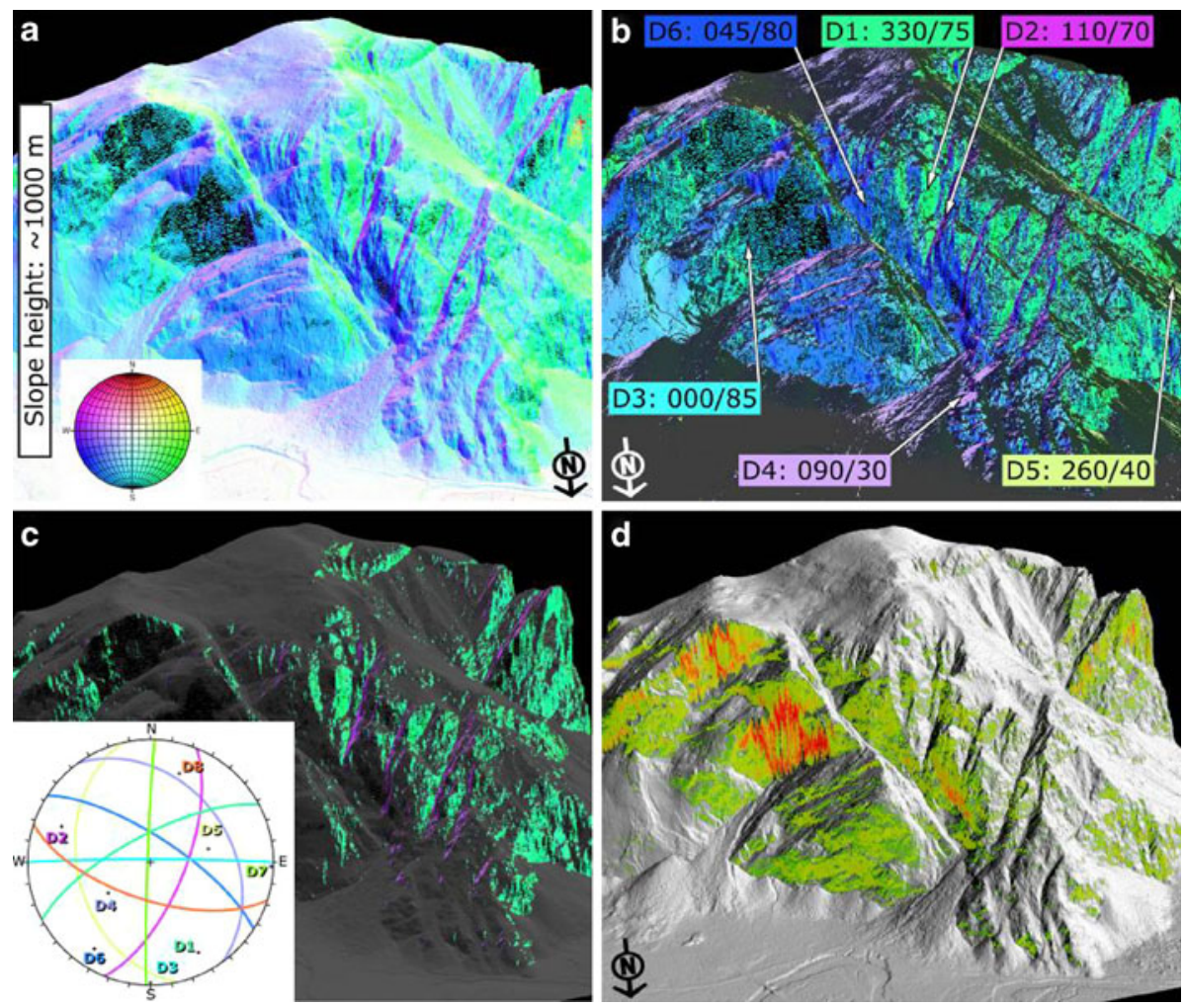

Fig. 4 ALS-DEM from Yosemite National Park (by courtesy of G. Stock). a COLTOP coloured DEM. b Identified discontinuity sets. c Discontinuities D1 and D2 forming a wedge that promoted instabilities. d Relative density of daylighting D1-D2 wedges the topography 


\subsubsection{TLS}

TLS characterization of rock slopes are among the first applications using TLS for slope mass movement, mainly to obtain accurate slope profile and discontinuity sets orientations (Bornaz et al. 2002; Slob et al. 2002). A technical report of the US Department of Transportation (Kemeny and Turner 2008) provides a brief introduction of the main commercial hardware and softwares and best practices for fieldwork campaigns.

Several studies are proposing different ways to characterize discontinuity sets, which can be mainly classified as (a) using fitting planes (Fernández 2005; Abellan et al. 2006; Oppikofer et al. 2008; Sturzenegger and Stead 2009), (b) using TIN surfaces as indicators of the plane orientations (Feng et al. 2001; Slob et al. 2002). A description of the methodology employed for rockmass characterization using the commercial software Split-FX is provided in Kemeny and Post (2003) and Kemeny and Turner (2008). Several authors (Lato et al. 2009; Abellán et al. accepted) have shown that there is an optimal number of points for the point cloud to get reliable results depending on the precision of the device: a sparse TIN suffers from smoothening over corners and edges, creating inaccuracies in plane representation. On the other hand, a dense TIN is affected by data noise. (c) Other techniques allow for the automatic delimitation of a set of neighbourhood points characterized by the same normal vector. As a result, the calculation of the orientation of the discontinuity planes is obtained. The COLTOP technique (Jaboyedoff et al. 2004a, 2007, 2009b; Derron et al. 2005) permits to visualize the orientation of each discontinuity set by a unique colour, which makes the approach very similar to a field data acquisition (COLTOP-3D, www.coltop3d.ch). The extracted data permit to analyse the rock instability mechanisms (Janeras et al. 2004; Jaboyedoff et al. 2008b; Oppikofer et al. 2009).

Different authors have pointed out the existence of two types of biases in the determination of the orientation of discontinuities (e.g. Sturzenegger and Stead 2009; Lato et al. 2009): (a) scale bias, when discontinuity sets are smaller than the spatial resolution (point spacing) and (b) orientation bias, when the incidence angle of a given data set influences the spatial resolution, and hence, the number of poles in stereonet when doing automatic procedures.

Another area of application that is merging in rock slope characterization is the roughness determination (Fardin et al. 2004; Haneberg 2007; Tatone and Grasselli 2009) aimed to better quantify the well-known methods for rock mass rating systems (Romana 1993). Nevertheless, certain limitations are linked to the achievement of this aim, such as the intrinsic instrumental accuracy, resolution and the influence of different scanner positions on the final results (Sturzenegger et al. 2007b). Although these limitations, further studies are necessary due to the great potential of such methods assuming selfsimilarity hypothesis (Fardin et al. 2004).

\subsection{Debris-flow}

ALS-derived DEM gives an accurate topography and permits to identify morphologies that are significant in order to characterize the past activity. To this end, morphometric indicators such as roughness, and curvature of the slope are used (Staley et al. 2006; Cavalli and Marchi 2008). This approach gives quite good results in discriminating the past debrisflow activity (Cavalli and Marchi 2008) but presents some limitations (Staley et al. 2006). The variograms inspection gives promising results for characterization of the landforms (Trevisani et al. 2009).

TLS has also been used to assess limited sections of channels, allowing very detailed mapping and section profiles evolution (Oppikofer 2009; Theules et al. 2009). 


\section{Hazard assessment, susceptibility mapping and modelling}

\subsection{Landslide}

\subsubsection{ALS}

One of the earliest applications of ALS-DEM in landslide susceptibility mapping and modelling is the work of Dietrich et al. (2001) (see also Montgomery et al. 2000). They showed that a $1 \mathrm{~m}$ resolution ALS-DEM improved greatly the results of the model SHALSTAB, an infinite slope stability model. One of the most achieved study of landslide hazard assessment using ALS-DEM is the one made by the USGS on the Puget Sound area (Washington state; Baum et al. 2005). In this study, field investigation is coupled with HRDEM analysis and shallow landslide modelling using TRIGRS (Savage et al. 2003), a sophisticated infinite slope model including transient infiltration. This study demonstrates improvements provided by ALS-DEM for hazard mapping. Along the same line, Haneberg et al. (2009) have shown convincing results for shallow landsliding, coupling an infinite slope model with geomorphic characterizations using an ALS-DEM.

Of course, the traditional hazard mapping by field investigation is improved by ALSDEM, especially for inventories but also for characterizing the susceptibility using morphometric indicators (Chigira et al. 2004; Haneberg et al. 2005; Jaboyedoff et al. 2008a). We can also expect that it will soon possible to infer hazard by comparing several ALSDEM of different epochs. This was already proposed by Chigira et al. (2004) who emphasized the possibility to use two inventories to assess hazard, but in their application the first inventory was still produced by field work only.

The ALS-DEM allows a detailed delimitation of the landslides on the topographical surface (van den Eeckhaut et al. 2007; Corsini et al. 2009). Using these limits and the DEM, it is possible to infer the failure surface in 3D. For instance, the sloping base level (SLBL) concept (Jaboyedoff et al. 2004b, 2009b) makes it possible to obtain very quickly a planar or curved quadratic surface by using simple geometrical rules. For example, Fig. 2 shows La Frasse landslide in the Swiss Alps and the expected failure surface of a fastmoving part.

\subsubsection{TLS}

TLS is mostly used for characterization or monitoring of landslides and not really for hazard mapping. Nevertheless, TLS can greatly improve the site-specific modelling, especially when the topography is changing and if only a poor DEM is available. For example, a detailed slope profile extracted from a TLS-DEM has permitted to identify the destabilized zone of an earth-flow using a standard Bishop analysis (Jaboyedoff et al. 2009c).

\subsection{Rockfall}

\subsubsection{ALS}

Regional rockfall hazard or susceptibility assessment from source area to rockfall propagation using ALS-DEM is not yet implemented as a routine, although all the pieces of the puzzle are present. The first issue is to locate the source areas. This is often performed at 

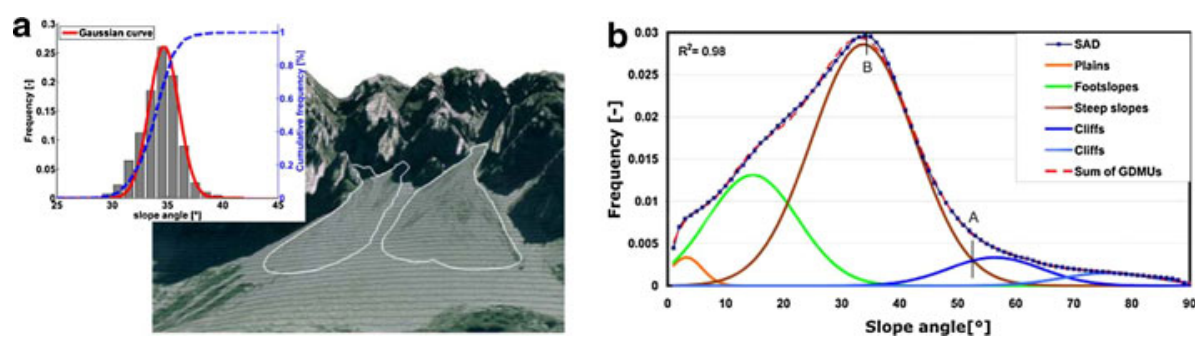

Fig. 5 Example of the slope angle distribution (SAD) computed on a ALS-DEM: a SAD of an undisturbed scree slope (outlined in white) showing that the slope angle values follow a normal distribution around an average value close to $35^{\circ}$. b SAD of an alpine valley decomposed into 5, Gaussian distributions; " $A$ " indicates the threshold angle above which the slope belongs dominantly to the cliffs and is therefore considered as potential rockfall source area; " $B$ " indicates the mode of GDMU steep slopes. The two cliffs Gaussian distributions represent two families of bare rock cliff faces lithologically distinct (modified after Loye et al. 2009)

regional scale using simple slope angle thresholds (Guzzetti et al. 2003; Frattini et al. 2008). But, as shown by Loye et al. (2009), more information can be potentially extracted from the slope angle distribution. By decomposing the histogram of slope angles of an area into Gaussian distributions, it is possible to identify the threshold above which the relief is dominantly composed of cliffs (Fig. 5). This threshold depends on the type of bedrock, the presence or absence of a soil cover and the DEM resolution (Loye et al. 2009). This method makes it possible to discriminate efficiently the true cliffs from the one drawn on topographic maps. In addition, as proposed by Günther (2003) and Jaboyedoff et al. (2004c), structural analysis performed on ALS-DEM (Fig. 4) can be the basis for kinematic test. As discussed in Janeras et al. (2004), the accuracy of the results is greatly improved by using a HRDEM.

Hazard assessment requires often performing trajectographic modelling in order to delineate the propagation area. The modelling has been greatly improved by the ALS-DEM (Agliardi and Crosta 2003; Lan et al. 2007) by introducing more dispersion in the propagation (Fig. 6), as demonstrated by Agliardi and Crosta (2003). In addition, the kinetic energy profile is greatly modified when the resolution of the DEM is increased. Both parameters are of primary importance for hazard mapping and dimensioning of mitigation measures.

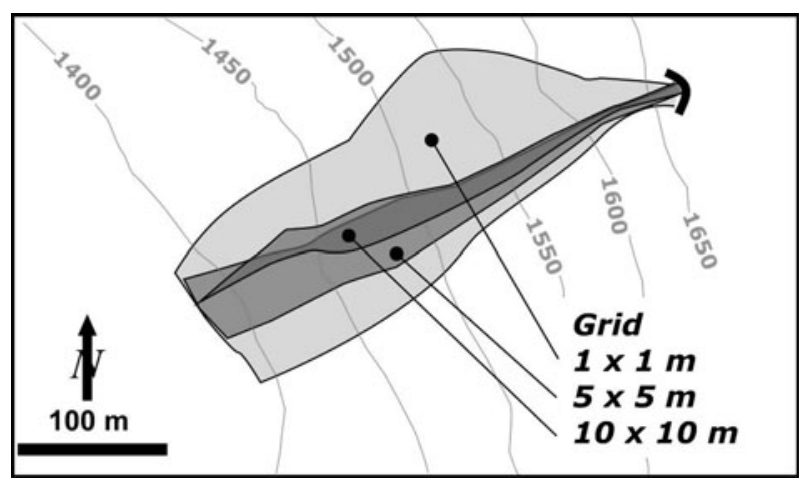

Fig. 6 Influence of the DEM mesh size in the scattering of the rockfall trajectories (after Agliardi and Crosta 2003) 


\subsubsection{TLS}

A great improvement in the rockfall hazard assessment is the monitoring of fallen blocks from a cliff between two epochs or more (Rosser et al. 2005; Lim et al. 2006; Lato et al. 2009; Abellan et al. 2010; Pedrazzini et al. 2010). Indeed, such approaches allow for the quantification of the magnitude and activity of rockfalls in a cliff. Rosser et al. (2007) quantified the increase in rockfall activity some months previous to the occurrence of larger events. Similarly, when this activity decreases, it may be inferred that the potential instability becomes stabilized during a given period (Pedrazzini et al. 2010). In addition, new methods of mobile terrestrial LIDAR along road cuts already produce detailed 3D models that provide data for structural analysis. If such acquisitions are repeated over time, they can be used to detect the most active areas (Lato et al. 2009).

\subsection{Debris-flow}

As suggested by different authors (e.g. Jakob 2005; Horton et al. 2008), process-based modelling of debris-flows is a difficult task because of the complexity of the phenomenon and the variability of controlling factors. Detailed topography (slope angle of channels as well as the channel profile) together with the available channel material can be critical parameters (Hungr 2005).

These are the major input from both ALS- and TLS-DEM, and they are critical to assess properly the volumes that can be mobilized. Based on the topography curvature of ALSDEM and other properties, it is also possible to extract potential source areas for debrisflows (Horton et al. 2008). The second improvement provided by ALS-DEM is the possibility to improve the modelling of propagation, despite the fact that computing time is very high if a full resolution ALS-DEM is used to compute the models on large areas. Similarly to rockfall modelling, Stolz and Huggel (2008) have shown that the modelling of debris-flows can be really improved by using HRDEM. Nevertheless, it must be emphasized that as a channel is a dynamic body and breakouts are always possible, a full resolution approach can also be a pitfall for models. For instance road embankments on the HRDEM are diverting flow, while in reality road bridges often exist to let the flow pass. Nevertheless, ALS-derived HRDEM with reduced resolution $(10 \times 10 \mathrm{~m})$ permits to obtain very good results for propagation calculations at regional scale (Horton et al. 2008).

\section{Monitoring}

\subsection{Landslide}

Before the existence of remote sensing techniques such as LIDAR, RADAR and photogrammetry, landslide monitoring was based on single-point measurements, using either GPS or total stations. But obtaining the complete field of displacements for the whole landslide is of great help to understand landslide kinematics and failure mechanism (Fig. 7). Laser scanning is nowadays a common tool for displacement monitoring even if few published papers exists. The basic principle is the same for both ALS- and TLS-DEM, requiring at least two epochs of HRDEM acquisition. Nevertheless, as monitoring requires both high resolution and high precision data sets, most of the works have been done up to now using TLS-derived HRDEMs. The results are either vectors between two points (or common areas) or distances between two data sets (point to surface comparison) either in a 

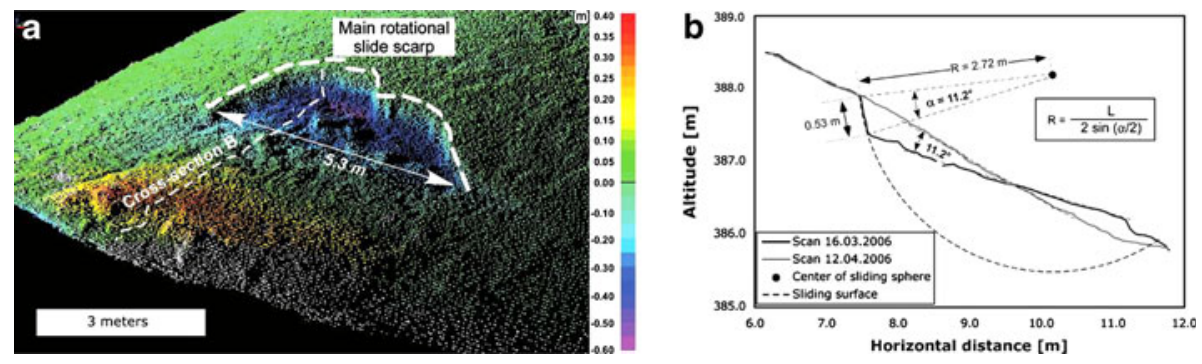

Fig. 7 Example of interpretation of landslide mechanism by using two successive TLS-DEMs performed on the 16 March and 12 April 2006 along the Sorge river (Switzerland). a Altitude difference between the scans and b interpretation of the cross-section showing a rotational landslide (modified after Jaboyedoff et al. 2009a)

user-defined direction or as shortest distance (Hausdorff distance) between the two surfaces. This difference calculation allows for the computation of volume differences, as is discussed by different authors (Bitelli et al. 2004; Chen et al. 2006; Corsini et al. 2007; Teza et al. 2007; Dewitte et al. 2008; Jaboyedoff et al. 2009a; Prokop and Panholzer 2009; Mueller and Loew 2009; Avian et al. 2009; Baldo et al. 2009).

The standard deviation of the measurements between two epochs can be quite high, depending on multiple factors, such as the quality of the TLS data sets, the density of points, the existence of vegetation, the roughness of the relief, the quality of the alignment between the scans, the relative or absolute positions of the TLS and the variation of the surface of the terrain between the two epochs. For instance, these values were not less than $5 \mathrm{~cm}$ at $100 \mathrm{~m}$ for Prokop and Panholzer (2009), or $3 \mathrm{~cm}$ for a $300 \mathrm{~m}$ range for Teza et al. (2008). In our recent experiences, it is possible to compare TLS data sets acquired consecutively and reach values of the standard deviation of around $1 \mathrm{~cm}$ for close ranges (less than $100 \mathrm{~m}$ ) and high point densities. This is in agreement with the results obtained on the "fast" moving landslide of Super-Sauze (France) where it was possible to measure velocities of $3.2 \mathrm{~cm} /$ day (Travelletti et al. 2008).

The low number of monitored landslides using ALS-derived HRDEM is due to the lower precision of ALS compared to TLS ( $\sim 15 \mathrm{~cm}$ vs. $\sim 1.5 \mathrm{~cm})$. As a result, comparison of such HRDEM requires a longer period between two acquisitions to obtain reliable results. Nevertheless, using classical photogrammetry on ancient aerial photos, it is possible to obtain displacement maps simply comparing objects locations on the pictures and on the ALS-DEM (Roering et al. 2009; Baldo et al. 2009).

\subsection{Rockfall}

Monitoring surface displacements in rock slopes is, in a way, simpler than in soil slopes because the displacements can be considered as rigid body transformations (Teza et al. 2007; Monserrat and Crosetto 2008; Abellan et al. 2009; Oppikofer et al. 2009). As a consequence, it is easier to identify and decompose the movements as a combination of translations and rotations of different parts of the slope. A good example for monitoring surface displacements is the huge slope displacements that occurred at the eastern flank of the Eiger (Switzerland), which was moving by more than $70 \mathrm{~cm} /$ day during the paroxysmal activity (Oppikofer et al. 2008). The detailed displacement analysis using the rigid body transformations of the upper part of the Åknes rockslide in Norway combined with 
detailed structural analysis allowed to derive the possible landslide mechanism (Oppikofer et al. 2009). Recent developments improved this methodology by introducing Euler angles to describe the rotational movement of the Cinque Torri rock towers in Italy (Viero et al. 2010).

Together with these monitoring results, the possibility to link spatial and temporal prediction of rockfalls constitutes a great challenge for landslide monitoring. Indeed, two different precursory indicators are currently being investigated: (1) the increase in rockfall activity before the final collapse, shown by Rosser et al. (2007) for a hard rock cliff at the coast of Staithes (UK); (2) the detection of precursory displacements is investigated for large rockfalls (e.g. $125 \mathrm{~cm} /$ day preceding a $170,000 \mathrm{~m}^{3}$ partial collapse of the Eiger rockslide, Oppikofer et al. 2008) and fragmental rockfalls (e.g. centimetric displacements preceding rockfalls with few to hundred cubic metres, Abellan et al. 2009, 2010) (Fig. 8). Although in certain cases precursory movements can be of the same order of magnitude than instrumental errors, different authors have observed that errors can be considerably reduced by taking into account the information of the neighbouring points, i.e. noise reduction by filtering or averaging (Lindenbergh and Pfeifer 2005; Monserrat and Crosetto 2008; Abellan et al. 2009). As an example, it was shown that it is possible to detect millimetric surface displacements in an outdoor experiment, even if single points had a higher standard deviation (Abellan et al. 2009).

\subsection{Debris-flow}

As we already mentioned, it is possible to monitor the channel changes using TLS (Oppikofer 2009; Theules et al. 2009) (Fig. 9). Recently, Scheidl et al. (2008) were able to compare two deposition areas of debris-flows that occurred during the heavy rainfall of August 2005 in Switzerland using two ALS-DEM acquisitions. They obtained good results but still with high errors that can reach more than $50 \%$ for eroded volumes, which is probably overestimated because the errors are computed pixel by pixels.

\section{Discussions and perspectives}

The real use for landslide studies of HRDEM from ALS or TLS started in 2000, although some developments started in the 1960s. For ALS this comes from the fact that GPS has
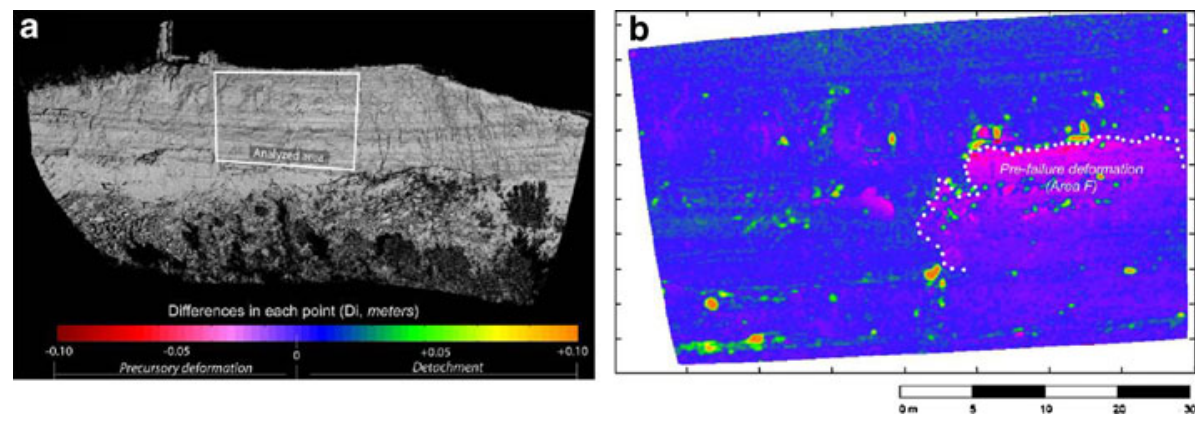

Fig. 8 Spatial prediction of rockfalls through the detection of pre-failure deformation using TLS. a Study area and analysed area; b comparison of TLS data sets during a time span of 303 days. Colour scale from -0.1 up to $0.1 \mathrm{~m}$ (after Abellan et al. 2010) 


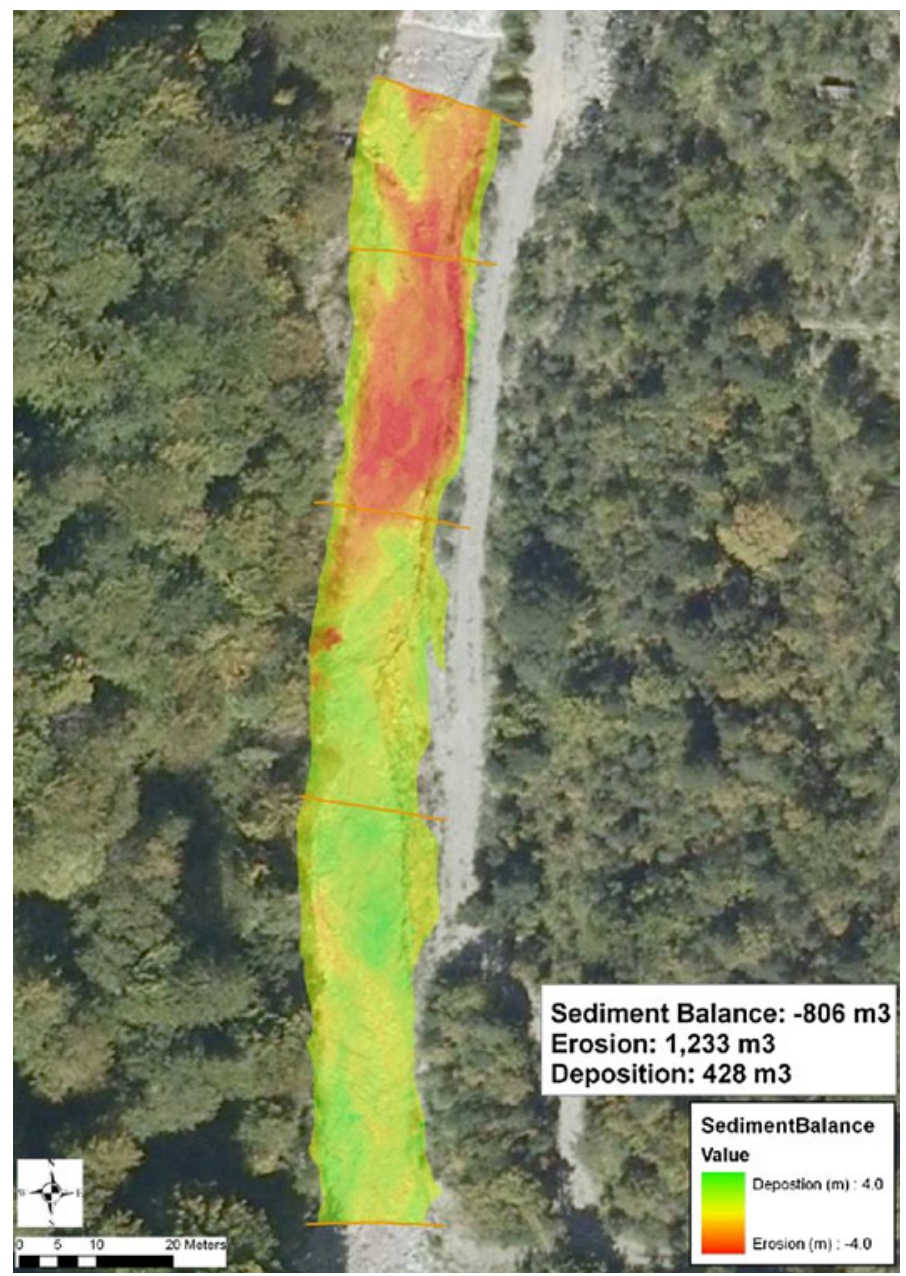

Fig. 9 Sediment budget calculated by the subtraction of two TLS data sets of the bed of the Manival torrent (France) (modified after Theules et al. 2009)

become available for public application during the mid-1990s. The TLS device market developed later because of the lack of software for 3D data processing and problems for handling huge amount of data (point clouds with several millions of points).

Main advantages of the technique are the acquisition of real 3D information, the fast data acquisition, easy set up and portability and its high resolution, at least for the groundbased instrument. Reversely, the main limitations of the ground-based technique are the existence of shadow areas caused by rugged topography, the huge quantity of acquired information and the needed post-processing techniques for filtering and alignment of the data sets, i.e. when a large area is scanned, several data sets must be merged and due to error propagation the alignment started to be more complicated and time-consuming to obtain reliable results.

As we have seen the number of applications is increasing very quickly. This is underlined by the fact that the recent syntheses about landslides risk include laser scanning 
and HRDEM as important tools (Van Westen et al. 2006; Fell et al. 2008; Derron and Jaboyedoff 2010). Figures including LIDAR images are presently published in papers without any other information, which means that it is now considered as a routine method demonstrative enough to be self-explanatory (Jibson 2006).

All the presented applications indicate that research has not yet well defined the limit of the LIDAR techniques, without taking into account the future advances, especially for monitoring purposes. It is clear that HRDEM is an inestimable support not only for landslide mapping, but also for hazard assessment. The use of the full data quality for modelling purposes is still not achieved.

LIDAR intensity provides some information on the material type, but it remains a difficult task to discriminate different materials (e.g. lithologies) based on the laser reflectivity because of the various causes of intensity variations. This has been applied with good results to the classification of river bed at different epochs by identifying water-land boundary (Höfle et al. 2009). Some research groups are now looking at further refinement of LIDAR imaging coupled with other remote sensing techniques. LIDAR data sets merged with RGB colours obtained from optical camera were tested on the Vesuvius crater providing encouraging results but is still far from an operative one (Pesci et al. 2007, 2008). Coupled with LIDAR data sets, the hyperspectral camera permits to get additional information on rock characteristics (Kurz et al. 2008).

One of the most promising advances is probably to analyse simultaneously InSAR results and HRDEM. The problem is to obtain coherent results between LOS distance changes from InSAR data and the 3D displacement vector extracted from LIDAR data. In any case, the first results are already consistent for TLS (Teza et al. 2008) and for ALS (Roering et al. 2009).

\section{Conclusions}

Above synthesis and considerations shows that HRDEM is increasingly being used in the landslide community, becoming an essential tool for landslide risk management s.l. In a few years, LIDAR sensors will probably be a standard tool for landslide analysis. Following the current trend, full coverage by ALS-DEM in most of the rich countries will be reached within the next 10 years. As the technique is also progressing, more accurate and precise ALS and TLS devices will appear, allowing for the generation of more accurate DEM. In addition, the vertical cliffs will certainly be also better imaged by new equipments, such as helicopter-based LIDAR sensors. Nevertheless, the huge amount of data will remain a problem as the computers will need to be more powerful with increasing data acquisition capacity as it is already the case with mobile LIDAR systems that have an acquisition rate of up to $200 \mathrm{kHz}$.

The real challenge is to develop new methods to better take benefit from HRDEM. Indeed a lot of new information can be extracted from such DEM that we not yet contrived to do. Although great advances have been developed in geometrical aspects, most of the conceptual models remain tied to the past. Could we combine these accurate HRDEM with a better modelling of landslide mechanisms (including rockfalls and debris-flows)? Is it possible to integrate surface measurements with early warning systems? The challenge for HRDEM exploitation is not only linked to landslide but also for instance to the analysis of fracturing at the surface using HRDEM and its extrapolation to underground. 
Acknowledgments We are grateful to the National Swiss Foundation for Science project Number 200021118105 and the EU project SafeLand (Grant Agreement No: 226479). We thank Dr. Greg Stock, geologist at Yosemite National Park, for providing us LIDAR data and J. Theules from CEMAGREF (Grenoble, France) who provided us one figure for illustrating TLS and debris-flows. In addition we are grateful to Marie Charrière and Florian Humair for editing some parts of the texts. The three anonymous reviewers are acknowledged for their valuable comments that helped us to improve the manuscript.

Open Access This article is distributed under the terms of the Creative Commons Attribution Noncommercial License which permits any noncommercial use, distribution, and reproduction in any medium, provided the original author(s) and source are credited.

\section{References}

Abellan A, Vilaplana JM, Martinez J (2006) Application of a long-range terrestrial laser scanner to a detailed rockfall study at Vall de Nuria (Eastern Pyrenees, Spain). Eng Geol 88:136-148. doi:10.1016/ j.enggeo.2006.09.012

Abellan A, Jaboyedoff M, Oppikofer T, Vilaplana JM (2009) Detection of millimetric deformation using a terrestrial laser scanner: experiment and application to rockfall event. Nat Hazards Earth Syst Sci 9:365-372. doi:10.5194/nhess-9-365-2009

Abellan A, Vilaplana JM, Calvet J, Blanchard J (2010) Detection and spatial prediction of rockfalls by means of terrestrial laser scanning modelling. Geomorphology 119:162-171. doi:10.1016/j.geomorph. 2010.03.016

Abellan A, Vilaplana JM, Calvet J, Garcia-Sellès D, Asensio E (accepted) Rockfall monitoring by terrestrial laser scanning. Case study of the basaltic rock face at Castellfollit de la Roca (Catalonia, Spain). Nat Hazards Earth Syst Sci

Agliardi F, Crosta GB (2003) High resolution three-dimensional numerical modelling of rockfalls. Int J Rock Mecha Mining Sci 40:455-471. doi:10.1016/S1365-1609(03)00021-2

Agliardi F, Crosta GB, Zanchi A, Ravazzi C (2009) Onset and timing of deep-seated gravitational slope deformations in the eastern Alps, Italy. Geomorphology 103:113-129. doi:10.1016/j.geomorph.2007. 09.015

Ardizzone F, Cardinali M, Galli M, Guzzetti F, Reichenbach P (2007) Identification and mapping of recent rainfall-induced landslides using elevation data collected by airborne Lidar. Nat Hazards Earth Syst Sci 7:637-650. doi:10.5194/nhess-7-637-2007

Armesto J, Ordóñez C, Alejano L, Arias P (2009) Terrestrial laser scanning used to determine the geometry of a granite boulder for stability analysis purposes. Geomorphology 106(3-4):271-277. doi:10.1016/ j.geomorph.2008.11.005

Avian M, Kellerer-Pirklbauer A, Bauer A (2009) LiDAR for monitoring mass movements in permafrost environments at the cirque Hinteres Langtal, Austria, between 2000 and 2008. Nat Hazards Earth Syst Sci 9:1087-1094. doi:10.5194/nhess-9-1087-2009

Baldo M, Bicocchi C, Chiocchini U, Giordan D, Lollino G (2009) LiDAR monitoring of mass wasting processes: The Radicofani landslide, Province of Siena, Central Italy. Geomorphology 105:193-201. doi:10.1016/j.geomorph.2008.09.015

Baltsavias EP (1999) Airbone laser scanning: basic relations and formulas. ISPRS J Photogramm Remote Sens 54:199-214. doi:10.1016/S0924-2716(99)00015-5

Baum RL, Coe JA, Godt JW, Harp EL, Reid ME, Savage WZ, Schulz WH, Brien DL, Chleborad AF, McKenna JP, Michael JA (2005) Regional landslide-hazard assessment for Seattle, Washington, USA. Landslide 2:266-279. doi:10.1007/s10346-005-0023-y

Besl P, McKay N (1992) A method for registration of 3-D shapes. IEEE Trans Pattern Anal Mach Intell 14:239-256. doi:10.1109/34.121791

Bitelli G, Dubbini M, Zanutta A (2004) Terrestrial laser scanning and digital photogrammetry techniques to monitor landslide bodies. In: Proceedings of the XXth ISPRS congress, Istanbul, Turkey, Commission $\mathrm{V}, \mathrm{WG} \mathrm{V} / 2$

Booth AM, Roering JJ, Perron JT (2009) Automated landslide mapping using spectral analysis and highresolution topographic data: Puget Sound lowlands, Washington, and Portland Hills, Oregon. Geomorphology 109:132-147. doi:10.1016/j.geomorph.2009.02.027

Borlat C, Epard JL, Jaboyedoff M (2007) Use of a laser-DTM for geological survey, structural interpretation and update of existing maps: example in the Jura Mountains (Switzerland). Geophys Res Abst 9:07424 
Bornaz L, Lingua A, Rinaudo F (2002) Engineering and environmental applications of laser scanner techniques. Int Archi Photogramm Remote Sens 34(3B):40-43

Brideau MA, Yan M, Stead D (2009) The role of tectonic damage and brittle rock fracture in the development of large rock slope failures. Geomorphology 103:30-49. doi:10.1016/j.geomorph.2008.04.010

Bromhead EN, Curtis RD, Schofield W (1988) Observation and adjustment of a geodetic survey network for measurement of landslide movement. In: Bonnard C, Balkema Publishers AA (eds) Proceedings of the 5th international symposium on landslides. Lausanne, Switzerland, pp 383-386

Carnec C, Massonnet D, King C (1996) Two examples of the use of SAR interferometry on displacement fields of small spatial extent. Geophys Res Lett 23(24):3579-3582. doi:10.1029/96GL03042

Carter W, Shrestha R, Tuell D, Bloomquist D, Sartori M (2001) Airborne laser swath mapping shines new light on earth's topography. Eos, Trans, Am Geophys Union 82(46):549, 550, 555

Cavalli M, Marchi L (2008) Characterisation of the surface morphology of an alpine alluvial fan using airborne LiDAR. Nat Hazards Earth Syst Sci 8:323-333. doi:10.5194/nhess-8-323-2008

Chen Y, Medioni G (1992) Object modelling by registration of multiple range images. Image Vis Comput 10:145-155. doi:10.1016/0262-8856(92)90066-C

Chen RF, Chang KJ, Angelier J, Chan YC, Deffontaines B, Lee CT, Lin ML (2006) Topographical changes revealed by high-resolution airborne LiDAR data: the 1999 Tsaoling landslide induced by the Chi-Chi earthquake. Eng Geol 88:160-172. doi:10.1016/j.enggeo.2006.09.008

Chigira M, Duan F, Yagi H, Furuya T (2004) Using an airbone laser scanner for the identification of shallow landslides and susceptibility assessment in an area of ignimbrite overlain by permeable pyroclastics. Landslides 3:203-209. doi:10.1007/s10346-004-0029-x

Colesanti C, Ferretti A, Prati C, Rocca F (2003) Monitoring landslides and tectonic motions with the permanent scatterers technique. Eng Geol 68:3-14. doi:10.1016/S0013-7952(02)00195-3

Corsini A, Borgatti L, Coren F, Vellico M (2007) Use of multitemporal airborne LiDAR surveys to analyse post-failure behaviour of earthslides. Can J Remote Sens 33(2):116-120

Corsini A, Cervi F, Daehne A, Ronchetti F (2009) Coupling geomorphic field observation and LIDAR derivatives to map complex landslides. In: Malet JP, Remaître A, Bogaard T (eds) Landslides processes-from geomorphologic mapping to dynamic modeling, proceedings of the landslide processes conference, 6-7 February 2009, Strasbourg

Cruden DM, Varnes DJ (1996) Landslides investigation and mitigation, transportation research board. In: Turner AK, Schuster RL (eds) Landslide types and process, National Research Council, National Academy Press, Special Report 247:36-75

Dallaire EE (1974) Electronic distance measuring revolution well under way. Civil Eng 44(10):66-71

Derron MH, Jaboyedoff M (2010) Preface to the special issue. In: LIDAR and DEM techniques for landslides monitoring and characterization. Nat Hazards Earth Syst Sci 10:1877-1879

Derron MH, Blikra LH, Jaboyedoff M (2005) High resolution digital elevation model analysis for landslide hazard assessment (Åkerneset, Norway). In: Senneset K, Flaate K, Larsen JA (eds) Landslide and avalanches, ICFL, pp 101-106

Dewitte O, Jasselette J-C, Cornet Y, Van Den Eeckhaut M, Collignon A, Poesen J, Demoulin A (2008) Tracking landslide displacements by multi-temporal DTMs: a combined aerial stereophotogrammetric and LIDAR approach in western Belgium. Eng Geol 99:11-22. doi:10.1016/j.enggeo.2008.02.006

Dietrich WE, Bellugi D, Real de Asua R (2001) Validation of the shallow landslide model, SHALSTAB, for forest management. In: Wigmosta MS, Burges SJ (eds) Land use and watersheds: human influence on hydrology and geomorphology in urban and forest areas, Water Science and Application, 2:195-227

Dunning S, Massey C, Rosser N (2009) Structural and geomorphological features of landslides in the Bhutan Himalaya derived from terrestrial laser scanning. Geomorphology 103:17-29. doi:10.1016/ j.geomorph.2008.04.013

Duong H (2006) Full waveform analysis: Icesat laser data for land cover classification. In: ISPRS commission VII mid-term symposium "remote sensing: from pixels to processes", pp 30-35

Fardin N, Feng Q, Stephansson O (2004) Application of a new in situ 3D laser scanner to study the scale effect on the rock joint surface roughness. Int J Rock Mech Min Sci 41:329-335. doi:10.1016/ S1365-1609(03)00111-4

Fell R, Corominas J, Bonnard C, Cascini L, Leroi E, Savage WZ (2008) Guidelines for landslide susceptibility, hazard and risk zoning for land use planning. Eng Geol 102:85-89. doi:10.1016/j.enggeo. 2008.03.022

Feng Q, Sjögren P, Stephansson O, Jing L (2001) Measuring fracture orientation at exposed rock faces by using a non-reflector total station. Eng Geol 59:133-146. doi:10.1016/S0013-7952(00)00070-3

Fernández O (2005) Obtaining a best fitting plane through 3D georeferenced data. J Struct Geol 27:855-858. doi:10.1016/j.jsg.2004.12.004 
Frattini P, Crosta G, Carrara A, Agliardi F (2008) Assessment of rockfall susceptibility by integrating statistical and physically-based approaches. Geomorphology 94:419-437. doi:10.1016/j.geomorph. 2006.10.037

Froese C, Moreno F, Jaboyedoff M, Cruden DM (2009) 25 years of movement monitoring on South Peak, Turtle Mountain: understanding the hazard. Can Geotech J 46:256-269. doi:10.1139/T08-121

Fruneau B, Achache J, Delacourt C (1996) Observation and modelling of the Saint-Étienne-de-Tinée landslide using SAR interferometry. Tectonophysics 265(3-4):181-190. doi:10.1016/S0040-1951 (96)00047-9

Glenn NF, Streutker DR, Chadwick DJ, Thackray GD, Dorsch SJ (2006) Analysis of LiDAR-derived topographic information for characterizing and differentiating landslide morphology and activity. Geomorphology 73:131-148. doi:10.1016/j.geomorph.2005.07.006

Gordon S, Lichti D, Stewart M (2001) Application of a high-resolution, ground-based laser scanner for deformation measurements. In: Proceedings of the 10th international FIG symposium on deformation measurements, Orange, California, USA, 19-22 March 2001, pp 23-32

Günther A (2003) Slopemap: programs for automated mapping of geometrical and kinematical properties of hard rock hill slopes. Comput Geosci 29(7):865-875. doi:10.1016/S0098-3004(03)00086-4

Guzzetti F, Reichenbach P, Wieczorek GF (2003) Rockfall hazards and risk assessment in the Yosemite Valley, California, USA. Nat Hazards Earth Syst Sci 3:491-503. doi:10.5194/nhess-3-491-2003

Habib A (2008) Accuracy, quality assurance and quality control of LIDAR data, Chap 9. In: Shan J, Toth CK (eds) Topographic laser ranging and scanning: principles and processing. CRC Press, Taylor \& Francis, pp 269-294

Haneberg WC (2007) Directional roughness profiles from three-dimensional photogrammetric or laser scanner point clouds. In: Eberhardt E, Stead D, Morrison T (eds) Rock mechanics: meeting society's challenges and demands. Proceedings of the 1st Canada-US rock mechanics symposium, Vancouver, Canada, May 27-31, 2007, Taylor \& Francis, pp 101-106

Haneberg WC, Creighton AL, Medley EW, Jonas DA (2005) Use of LiDAR to assess slope hazards at the Lihir gold mine, Papua New Guinea. In: Hungr O, Fell R, Couture R, Eberhardt E (eds) Proceedings of the international conference on landslide risk management. Vancouver, Taylor \& Francis Group, Supplementary Volume (CD), Canada

Haneberg WC, Cole WF, Kasali G (2009) High-resolution lidar-based landslide hazard mapping and modeling, UCSF Parnassus Campus; San Francisco, USA. Bull Eng Geol Environ 68:263-276. doi: 10.1007/s10064-009-0204-3

Harding D (2008) Pulsed laser altimeter ranging techniques and implications for terrain mapping, Chap 5. In: Shan J, Toth CK (eds) Topographic laser ranging and scanning: principles and processing. CRC Press, Taylor \& Francis, pp 173-194

Haugerud RA, Harding DJ, Johnson SY, Harless JL, Weaver CS, Sherrod BL (2003) High-resolution lidar topography of the Puget Lowland, Washington-A Bonanza for earth science. GSA Today 13:4-10

Heritage GL, Large ARG (2009) Laser scanning for the environmental sciences. Wiley-Blackwell, London

Hiremagalur J, Yen KS, Akin K, Bui T, Lasky, TA, Ravani B (2007) Creating standards and specifications for the use of laser scanning in CalTrans projects. Technical report no F/CA/RI/2006/46, California Department of Transportation, US (www.ahmct.ucdavis.edu/images/AHMCT_LidarFinalReport.pdf)

Höfle B, Vetter M, Pfeifer N, Mandlburger G, Stötter J (2009) Water surface mapping from airbone laser scanning using signal intensity and elevation data. Earth Surf Proc Land 34(12):1635-1649. doi: 10.1002/esp.1853

Hoge FE, Swift RN, Frederick EB (1980) Water depth measurement using an airborne pulsed neon laser system. Appl Opt 19(6):871-883. doi:10.1364/AO.19.000871

Horton P, Jaboyedoff M, Bardou E (2008) Debris flow susceptibility mapping at a regional scale. In: Locat J, Perret D, Turmel D, Demers D, Leroueil S (eds) 4th Canadian conference on geohazards: from causes to management, Presse de l'Université Laval, pp 399-406

Hungr O (2005) Classification and terminology. In: Jakob M, Hungr O (eds) Debris-flow hazards and related phenomena. Springer, Berlin/Heidelberg

Ingensand H (2006) Metrological aspects in terrestrial laser-scanning technology. In: Proceedings of the 3rd IAG/12th FIG symposium, Baden, Austria

Jaboyedoff M, Baillifard F, Couture R, Locat J, Locat P (2004a) New insight of geomorphology and landslide prone area detection using DEM. In: Lacerda WA, Ehrlich M, Fontoura AB, Sayao A (eds) Landslides evaluation and stabilization. Balkema, pp 191-197

Jaboyedoff M, Baillifard F, Couture R, Locat J, Locat P (2004b) Toward preliminary hazard assessment using DEM topographic analysis and simple mechanical modeling by means of sloping local base level. In: Lacerda WA, Ehrlich M, Fontoura AB, Sayao A (eds) Landslides evaluation and stabilization. Balkema, pp 199-205 
Jaboyedoff M, Baillifard F, Philipossian F, Rouiller JD (2004c) Assessing the fracture occurrence using the "Weighted fracturing density": a step towards estimating rock instability hazard. Nat Hazards Earth Syst Sci 4:83-93. doi:10.5194/nhess-4-83-2004

Jaboyedoff M, Metzger R, Oppikofer T, Couture R, Derron MH, Locat J, Durmel D (2007) New insight techniques to analyze rock-slope relief using DEM and 3D-imaging clouds points: COLTOP-3D software. In: Eberhardt E, Stead D, Morrison T (eds) Rock mechanics: meeting society's challenges and demands. Taylor \& Francis, London, pp 61-68

Jaboyedoff M, Pedrazzini A, Horton P, Loye A, Surace I (2008a) Preliminary slope mass movements susceptibility mapping using LIDAR DEM. In: Proceedings of 61th Canadian geotechnical conference, pp 419-426

Jaboyedoff M, Oppikofer T, Minoia R, Locat J, Turmel D (2008b) Terrestrial LIDAR investigation of the 2004 rockslide along Petit Champlain street, Québec City (Québec, Canada). In: Locat J, Perret D, Turmel D, Demers D, Leroueil S (eds) 4th Canadian conference on geohazards: from causes to management. Presse de 1'Université Laval, pp 295-301

Jaboyedoff M, Oppikofer T, Locat A, Locat J, Turmel D, Robitaille D, Demers D, Locat P (2009a) Use of ground-based LIDAR for the analysis of retrogressive landslides in sensitive clay and of rotational landslides in river banks. Can Geotech J 46:1379-1390. doi:10.1139/T09-073

Jaboyedoff M, Couture R, Locat P (2009b) Structural analysis of Turtle Mountain (Alberta) using digital elevation model: toward a progressive failure. Geomorphology 103:5-16. doi:10.1016/j.geomorph. 2008.04.012

Jaboyedoff M, Pedrazzini A, Loye A, Oppikofer T, Güell i Pons M (2009c) Earth flow in a complex geological environment: the example of Pont Bourquin, Les Diablerets (Western Switzerland). In: Malet JP, Remaître A, Bogaard T (eds) Landslides processes-from geomorphologic mapping to dynamic modeling, proceedings of the landslide processes conference, 6-7 February 2009, Strasbourg, France

Jakob M (2005) Debris-flow hazard analysis. In: Jakob M, Hungr O (eds) Debris-flow hazards and related phenomena. Springer, Berlin/Heidelberg

Janeras M, Navarro M, Arno G, Ruiz A, Kornus W, Talaya J, Barbera M, Lopez F (2004) LIDAR applications to rock fall hazard assessment in Vall de Nuria. 4th ICA Mountain Cartography Workshop, 30th September-2nd October 2004. Vall de Nuria, Catalonia, Spain

Jibson RW (2006) The 2005 La Conchita, California, landslide. Landslides 3:73-78. doi:10.1007/s10346005-0011-2

Kamerman GW (1993) Laser radar (chapter 1). In: Fox CS (ed) The infrared and electro-optical systems handbook. Infrared information analysis center. Ann Arbor, Michigan, pp 1-76

Kasai M, Ikeda M, Asahina T, Fujisawa K (2009) LiDAR-derived DEM evaluation of deep-seated landslides in a steep and rocky region of Japan. Geomorphology 113:57-69. doi:10.1016/j.geomorph. 2009.06.004

Keaton JR, DeGraff JV (1996) Surface observation and geologic mapping. In: Turner AK, Schuster RL (eds) Landslide types and process, National Research Council, National Academy Press, Special Report 247: 178-230

Kemeny J, Post R (2003) Estimating three-dimensional rock discontinuity orientation from digital images of fracture traces. Comput Geosci 29:65-77. doi:10.1016/S0098-3004(02)00106-1

Kemeny J, Turner K (2008) Ground based LIDAR. Rock slope Mapping and assessment. Technical report of the Central Federal Lands Highway Division US Department of Transportation FHWA-CFL/TD-08006 (www.iaeg.info)

Krabill WB, Collins JG, Link LE, Swift RN, Butler ML (1984) Airbone laser topographic mapping results. Photogramm Eng Remote Sens 50(6):685-694

Krabill WB, Thomas RH, Martin CF, Swift RN, Frederick EB (1995) Accuracy of airbone laser altimetry over Greenland ice sheet. Int J Remote Sens 16(7):1211-1222. doi:10.1080/01431169508954472

Krabill WB, Frederick EB, Manizade S, Martin CF, Sonntag J, Swift RN, Thomas R, Wright W, Yungel J (1999) Rapid thinning of parts of the southern Greenland ice sheet. Science 283:1522-1524. doi: 10.1126/science.283.5407.1522

Kurz TH, Buckley SJ, Howell JA, Schneider D (2008) Geological outcrop modeling and interpretation using ground based hyperspectral and laser scanning data fusion. Int Archi Photogramm Remote Sens 37(B8):1229-1234

Lan H, Martin CD, Lim CH (2007) RockFall analyst: a GIS extension for three-dimensional and spatially distributed rockfall hazard modeling. Comput Geosci 33(2):262-279. doi:10.1016/j.cageo.2006.05.013

Lato M, Diederichs M, Hutchinson DJ, Harrap R (2009) Optimization of LiDAR scanning and processing for automated structural evaluation of discontinuities in rockmasses. Int J Rock Mech Min Sci 46:194-199. doi:10.1016/j.ijrmms.2008.04.007 
Lichti DD (2007) Error modelling, calibration and analysis of an AM-CW terrestrial laser scanner system. ISPRS J Photogramm Remote Sens 61:307-324. doi:10.1016/j.isprsjprs.2006.10.004

Lichti DD, Jamtsho S (2006) Angular resolution of terrestrial laser scanners. Photogramm Rec 21:141-160. doi:10.1111/j.1477-9730.2006.00367.x

Lichti D, Stewart M, Tsakiri M, Snow A (2000) Benchmark tests on a three-dimensional laser scanning system. Geomat Res Australas 72:1-24

Lim M, Petley DN, Rosser NJ, Allison RJ, Long AJ, Pybus D (2006) Combined digital photogrammetry and time-of-flight laser scanning for monitoring cliff evolution. Photogramm Rec 20:109-129. doi: 10.1111/j.1477-9730.2005.00315.x

Lindenbergh R, Pfeifer N (2005) A statistical deformation analysis of two epochs of terrestrial laser data of a lock. In: Proceedings of the 7th conference on optical 3D measurement techniques, Vienna, Austria, pp $61-70$

Loye A, Jaboyedoff M, Pedrazzini A (2009) Identification of potential rockfall source areas at a regional scale using a DEM-based geomorphometric analysis. Nat Hazards Earth Syst Sci 9:1643-1653. doi: 10.5194/nhess-9-1643-2009

Manetti L, Steinmann G (2007) 3DeMoN ROBOVEC-integration of a new measuring instrument in an existing generic remote monitoring platform. In: 7th international symposium on field measurements in geomechanics, September 2007, Boston, MA, USA, pp 24-27

McKean J, Roering J (2004) Objective landslide detection and surface morphology mapping using highresolution airborne laser altimetry. Geomorphology 57:331-351. doi:10.1016/S0169-555X(03)00164-8

Miller B (1965) Laser altimeter may aid photo mapping. Aviat Week Space Technol 88(13):60-64

Monserrat O, Crosetto M (2008) Deformation measurement using terrestrial laser scanning data and least squares 3D surface matching. ISPRS J Photogramm Remote Sens 63:142-154. doi:10.1016/j.isprsjprs. 2007.07.008

Montgomery DR, Schmidt KM, Greenberg HM, Dietrich WE (2000) Forest clearing and regional landsliding. Geology 28:311-314. doi:10.1130/0091-7613(2000)28<311:FCARL $>2.0$. CO;2

Mueller R, Loew S (2009) Predisposition and Cause of the Catastrophic Landslides of August 2005 in Brienz (Switzerland). Swiss J Geosci 102(2):331-344. doi:10.1007/s00015-009-1315-3

Oppikofer T (2009) Detection, analysis and monitoring of slope movements by high-resolution digital elevation models. PhD Thesis, Institute of Geomatics and Analysis of Risks, Faculty of Geosciences and Environment, University of Lausanne, Switzerland

Oppikofer T, Jaboyedoff M, Keusen HR (2008) Collapse at the eastern Eiger flank in the Swiss Alps. Nat Geosci 1:531-535. doi:10.1038/ngeo258

Oppikofer T, Jaboyedoff M, Blikra L, Derron MH (2009) Characterization and monitoring of the Åknes rockslide using terrestrial laser scanning. Nat Hazards Earth Syst Sci 9:1643-1653. doi:10.5194/nhess9-1003-2009

Pedrazzini A, Oppikofer T, Jaboyedoff M, Guell i Pons, M, Chantry R, Stampfli E (2010) Assessment of rockslide and rockfall problems in an active quarry: case study of the Arvel quarry (western Switzerland). In: European rock mechanics symposium (EUROCK 2010), Lausanne, Switzerland. CRC Press, Leiden, pp 593-596

Pesci A, Loddo F, Conforti D (2007) The first terrestrial laser scanner application over Vesuvius: High resolution model of a volcano crater. Int J Remote Sens 28(1):203-219. doi:10.1080/014311605 00534473

Pesci A, Teza G, Ventura G (2008) Remote sensing of volcanic terrains by terrestrial laser scanner: preliminary reflectance and RGB implications for studying Vesuvius crater (Italy). Annals Geophys 51:619-631

Petrie G, Toth CK (2008) I. Introduction to laser ranging, profiling and scanning, II. Airbone and spaceborne laser profiles and scanners, III. Terrestrial laser scanners (chapters 1 to 3). In: Shan J, Toth CK (eds) Topographic laser ranging and scanning: principles and processing, CRC Press, Taylor \& Francis

Prokop A, Panholzer H (2009) Assessing the capability of terrestrial laser scanning for monitoring slow moving landslides. Nat Hazards Earth Syst Sci 9:1921-1928. doi:10.5194/nhess-9-1921-2009

Roering JJ, Stimely LL, Mackey BH, Schmidt DA (2009) Using DInSAR airbone LIDAR, and archival air photos to quantify landsliding and sediment transport. Geophys Res Lett 36:L19402. doi:10.1029/2009 GL040374

Romana M (1993) A geomechanical classification for slopes: slope mass rating. In: Hudson JA (ed) Comprehensive rock engineering, vol 3. Pergamon Press, Oxford, pp 553-573

Rosser NJ, Petley DN, Lim M, Dunning SA, Allison RJ (2005) Terrestrial laser scanning for monitoring the process of hard rock coastal cliff erosion. Q J Eng Geol Hydrogeol 38:363-375. doi:10.1144/14709236/05-008 
Rosser NJ, Lim N, Petley DN, Dunning S, Allison RJ (2007) Patterns of precursory rockfall prior to slope failure. J Geophys Res 112(F4). doi:10.1029/2006JF000642

Rowlands KA, Jones LD, Whitworth M (2003) Landslide laser scanning: a new look at an old problem. Q J Eng Geol Hydrogeol 36:155-157. doi:10.1144/1470-9236/2003-08

SafeLand deliverable 4.1 (2010) Review of techniques for landslide detection, fast characterization, rapid mapping and long-term monitoring. In: Michoud C, Abellán A, Derron M-H, Jaboyedoff M (eds) SafeLand European project. Available at http://www.safeland-fp7.eu

Savage WZ, Godt JW, Baum RL (2003) A model for spatially and temporal distributed shallow landslide initiative by rainfall infiltration. In: Rickenmann D, Chen C (eds) Debris-flow hazards mitigation: mechanics, prediction, and assessment. Millpress, Rotterdam

Scheidl C, Rickenmann D, Chiari M (2008) The use of airborne LiDAR data for the analysis of debris flow events in Switzerland. Nat Hazards Earth Syst Sci 8:1113-1127. doi:10.5194/nhess-8-1113-2008

Schulz WH (2007) Landslide susceptibility revealed by LIDAR imagery and historical records, Seattle, Washington. Eng Geol 89:67-87. doi:10.1016/j.enggeo.2006.09.019

Shan J, Toth K (2008) Topographic laser ranging and scanning: principles and processing. CRC Press, Taylor \& Francis Group, LLC, UK

Shepherd EC (1965) Laser to watch height. New Scientist 1:33

Singhroy V (2009) Satellite remote sensing applications for landslde detection and monitoring. In: Sassa K, Canuti P (eds) Landslides-disaster risk reduction. Springer, Berlin/Heidelberg, pp 143-158

Slob S, Hack R (2004) 3D terrestrial laser scanning as a new field measurement and monitoring technique. In: Engineering geology for infrastructure planning in Europe: a European perspective, Lectures Notes in Earth Sciences, Springer, Berlin/Heidelberg, 104:179-189

Slob S, Hack H, Turner AK (2002) An approach to automate discontinuity measurements of rock faces using laser scanning techniques. In: Dinid da Gama C, Riberia e Sousa L (eds) Proceedings of ISRM EUROCK 2002, 25-28 November 2002, Funchal, Portugal, Sociedade Portuguesa de Geotecnia, pp 87-94

Soeters R, van Westen CJ (1996) Slope stability: recognition, analysis and zonation. In: Turner AK, Schuster RL (eds) Landslides investigation and mitigation, Transportation Research Board, National Research Council, National Academy Press, Special Report 247:129-177

Squarzoni C, Delacourt C, Allemand P (2003) Nine years of spatial and temporal evolution of the La Valette landslide observed by SAR interferometry. Eng Geol 68:53-66. doi:10.1016/S0013-7952(02)00198-9

Staley DM, Wasklewicz TA, Blaszczynski JS (2006) Surficial patterns of debris flow deposition on alluvial fans in Death Valley, CA using airborne laser swath mapping data. Geomorphology 74:152-163. doi: 10.1016/j.geomorph.2005.07.014

Stolz A, Huggel C (2008) Debris flows in the Swiss National Park: the influence of different flow models and varying DEM grid size on modeling results. Landslides 5:311-319. doi:10.1007/s10346-0080125-4

Stow R (1996) Application of SAR interferometry to the imaging and measurement of neotectonic movement applied to mining and other subsidence/downwarp modeling. In: Fringe 96 proceedings ESA workshop on applications of ERS SAR interferometry, Zurich, Switzerland

Sturzenegger M, Stead D (2009) Quantifying discontinuity orientation and persistence on high mountain rock slopes and large landslides using terrestrial remote sensing techniques. Nat Hazards Earth Syst Sci 9:267-287. doi:10.5194/nhess-9-267-2009

Sturzenegger M, Stead D, Froese C, Moreno F, Jaboyedoff M (2007a) Ground-based and airborne LiDAR for structure mapping of a large landslide: the Frank Slide. In: Eberhardt E, Stead D, Morrison T (eds) Rock mechanics: meeting society's challenges and demands. Taylor \& Francis, London, pp 925-932

Sturzenegger M, Yan M, Stead D, Elmo D (2007b) Application and limitations of ground-based laser scanning in rock slope characterization. In: Eberhardt E, Stead D, Morrison T (eds) Proceedings of the first Canadian US rock mechanics symposium. Taylor \& Francis, London, pp 29-36

Tarchi D, Casagli N, Fanti R, Leva DD, Luzi G, Pasuto A, Pieraccini M, Silvano S (2003) Landslide monitoring by using ground-based SAR interferometry: an example of application to the Tessina landslide in Italy. Eng Geol 68:15-30. doi:10.1016/S0013-7952(02)00196-5

Tatone BS, Grasselli G (2009) A method to evaluate the three-dimensional roughness of fracture surfaces in brittle geomaterials. Rev Sci Instrum 80(12). doi:10.1063/1.3266964

Teza G, Galgaro A, Zaltron N, Genevois R (2007) Terrestrial laser scanner to detect landslide displacement fields: a new approach. Int J Remote Sens 28:3425-3446. doi:10.1080/01431160601024234

Teza G, Pesci A, Genevois R, Galgaro A (2008) Characterization of landslide ground surface kinematics from terrestrial laser scanning and strain field computation. Geomorphology 97:424-437. doi:10.1016/ j.geomorph.2007.09.003 
Theules JI, Loye A, Liébault F, Laigle D, Jaboyedoff M (2009) Sediment budget of a debris flow event in the French Prealps. American Geophysical Union Fall Meeting 2009

Travelletti J, Oppikofer T, Delacourt C, Malet J, Jaboyedoff M (2008) Monitoring landslide displacements during a controlled rain experiment using a long-range terrestrial laser scanning (TLS). Int Archi Photogramm Remote Sens 37(B5):485-490

Trevisani S, Cavalli M, Marchi L (2009) Variogram maps from LiDAR data as fingerprints of surface morphology on scree slopes. Nat Hazards Earth Syst Sci 9:129-133. doi:10.5194/nhess-9-129-2009

Vallet J, Skaloud J (2004) Development and experiences with a fully-digital handheld mapping system operated from a helicopter. Int Archi Photogramm Remote Sens 35(B5):791-796

Van Den Eeckhaut M, Poesen J, Verstraeten G, Vanacker V, Nyssen J, Moeyersons J, van Beek LPH, Vandekerckhove L (2007) Use of LIDAR-derived images for mapping old landslides under forest. Earth Surf Proc Land 32:754-769. doi:10.1002/esp.1417

Van Westen CJ, Van Asch TWJ, Soeters R (2006) Landslide hazard and risk zonation-why is it still so difficult? Bull Eng Geol Environ 65:67-184. doi:10.1007/s10064-005-0023-0

Viero A, Teza G, Massironi M, Jaboyedoff M, Galgaro A (2010) Laser scanning-based recognition of rotational movements on a deep seated 2 gravitational instability: The Cinque Torri case (NorthEastern Italian Alps). Geomorphology 122:191-204. doi:10.1016/j.geomorph.2010.06.014

Voegtle T, Schwab I, Landes T (2008) Influences of different materials on the measurement of a Terrestrial Laser Scanner (TLS). In: Proceedings of the XXI congress, the international society for photogrammetry and remote sensing, ISPRS2008, vol XXXVII, Commission V, 3-11 July 2008, Beijing, China, pp 1061-1066

Wehr A, Lohr U (1999) Airborne laser scanning-an introduction and overview. ISPRS J Photogramm Remote Sens 54:68-82. doi:10.1016/S0924-2716(99)00011-8 